\title{
Facebook Likes and Sport Brand Image: An Empirical Examination of the National Advertising Division's Coastal Contacts' Decision
}

\author{
Natasha T. Brison, Thomas A. Baker III, and Kevin K. Byon
}

\begin{abstract}
Eighty-six percent of companies surveyed in the 2013 Social Media Examiner Report indicated that they were using social media for marketing purposes. Similarly, many sport brands are also incorporating social media in their marketing strategies. Like-gating, the process of offering consumers a benefit in exchange for liking their Facebook pages, is a popular method brands use to connect with consumers through Facebook. The National Advertising Division (NAD), a dispute resolution agency for claims related to national advertisements, recently determined that Facebook likes and the number of likes are a form of social endorsement and advised marketers that Facebook likes should be genuine endorsements for the brand. This study tested whether the NAD's concerns were justified, and thus warranting additional regulatory action by the NAD, by examining whether the number of Facebook likes for a sport brand creates an endorsement effect, thus influencing brand image and consumer purchase intention. The results indicated a strong relationship between the number of Facebook likes, a consumer's perception of the brand, and likelihood of purchase.
\end{abstract}

When advertising through radio and television were the only means of capturing the attention of consumers, a commercial could reach $70 \%$ of the viewing audience (Johnson, 2009). Today, the average consumer may be exposed to more than 5000 advertisements per day through traditional forms of media and digital technology (Romanik, 2011), and the ability of brands to be differentiated among competing media has become extremely challenging for marketers. Recent reports indicated that $74 \%$ of the population in the United States are using social media on a monthly basis (Pew Research Center, 2014), and as a result, social media outlets have become popular mechanisms for brands to connect with consumers. Companies have found that unlike traditional marketing efforts, social media provides brands with direct access to consumers and is an acceptable medium to influence consumer perceptions of brand image (Bolotaeva \& Cata, 2011; Du, Bhattacharya, \& Sen, 2010).

Brison (natasha.brison@tamu.edu) is with the Dept. of Health and Kinesiology, Texas A\&M University, College State, TX. Baker is with the Dept. of Kinesiology, University of Georgia, Athens, GA. Byon is with the Dept. of Kinesiology, Indiana University, Bloomington, IN. 
Notably, with the increased use of social media by marketers and advertisers, there has also been a rise in the necessity for regulation of campaigns encompassing these platforms. As of April 2010, the National Advertising Division (NAD), a self-regulatory agency tasked with monitoring advertisements in the United States, has investigated approximately 419 cases (BBB.org, 2014). Of those cases, the terms Facebook, Twitter, YouTube, Pinterest, social media, and blogs arose 107 times, with cases involving Facebook occurring the most frequently (BBB.org, 2014). The increase in these cases has stressed the importance of the NAD's role in regulation of consumer advertisements through social media as well as the demand for marketing research to assist the NAD in determining where regulation may be needed. Moreover, research is needed to guide the NAD in making regulatory decisions that protect consumers, yet provide marketers with reasonable limits in the use of social media platforms as marketing mediums. Research is also needed to guide marketers in regulatory compliance and with understanding the potential impact NAD decisions may have on marketing practices involving social media.

The foremost social media platform used by marketers is Facebook; this is also evidenced by Facebook's prominence in NAD investigations. With more than 1 billion monthly active users ("Facebook Newsroom," 2014), Facebook has become a widely used gateway for linking businesses with consumers. Through Facebook, brands are able to create a profile and add friends to the profile, and when used appropriately, a brand's Facebook page may serve as an invaluable vehicle to assess what the marketplace is saying about the brand and its products.

In April 2010, Facebook replaced its 'Become a Fan' feature with a 'Like' button. The social networking site hoped the function would be considered more inconsequential and would increase the number of contacts made through the site (McBurney, 2012). Since this change, one of the most accepted methods brands are using to drive consumers to their Facebook pages is a practice called 'like-gating.' The practice encourages consumers to like or endorse companies on Facebook in exchange for something (Aronica, 2011), resulting in a high number of likes on the company Facebook page. According to a report in EMarketer, three out of five Facebook users have liked a brand within the last six months (Cohen, 2012), and consumers typically expect any legitimate brand to have a Facebook page (Razorfishsearch.com, 2011). The question, however, is whether liking a brand's Facebook page is a form of endorsement of the brand. In a study conducted by EMarketer, 58\% of Facebook users said they only liked a page to receive discounts and coupons; $37 \%$ of those in the same study reported the like meant nothing to them (i.e., it does not mean they are fans of the brand; The Facebook Like, 2011).

For brands, like-gating helps to increase brand awareness and brand image. Like-gating also allows brands to provide consumers who visit their Facebook pages the perception of brand or company quality, stability, and even popularity. For potential sport consumers who are researching brands before making purchases, what do the likes mean? For example, Reebok has 3.4 million likes ("Reebok," 2014), and New Balance has 866,000 likes ("New Balance," 2014). Given that $60 \%$ of consumers learn about a specific brand or retailer through social networking sites ("How Social Media Impacts Brand Marketing," 2011), does this mean that Reebok is four times better than New Balance? In another study conducted by EMarketer, 35\% of those surveyed said that "seeing Facebook likes on a product would increase the likelihood that they will buy the product ("The Facebook 
Like," 2011, para. 8). Therefore, this also poses the question of whether like-gating practices may be misleading to sport consumers who use social media websites to research products because they could be influenced by the number of likes on a brand's Facebook page. Researchers have asserted that the number of likes does not measure actual sales or purchase intention (Manjoo, 2011); however, there is limited research related to how sport consumers perceive the volume of likes on a brand's Facebook page and whether the volume of Facebook likes influences purchase intention.

Despite any evidentiary support for the perception that like-gating is a deceptive practice, the NAD took investigative and regulatory action in regards to the practice of like-gating in its Coastal Contacts case. In Coastal Contacts, the NAD determined that Facebook likes are a "general social endorsement" of the company (Coastal, 2011, p. 1). The NAD's position is that like-gating, which increases the number of likes on a brand's Facebook page, may be misleading to customers who view likes as endorsements for a brand and rely on the volume of likes to influence purchase intention (Coastal, 2011). The sport industry is not immune from this phenomenon, and additional research is needed to determine whether Facebook likes function as a form of endorsement for sport brands and whether Facebook likes have the same influence as traditional endorsements on brand image.

Previous social media studies in sport have included the use of social media as a brand management tool in collegiate athletics, identification of predictors of consumer usage to follow sport organizations through social media, an examination of adolescent sport participation through social media, and how social media should be a part of the new promotion mix (Mahan, 2011; Mangold \& Faulds, 2009; O’Reilly, Berger, Hernandez, Parent, \& Seguin, 2012; Wallace, Wilson, $\&$ Miloch, 2011). In addition, the effectiveness of endorsers has been examined from the perspective of source attractiveness and expertise (Till \& Busler, 2000), endorser celebrity status (Petty, Cacioppo, \& Schumann, 1983), the number of products endorsed (Tripp, Jensen, \& Carlson, 1994), and the number of sources in advertising appeals (Moore, Mowen, \& Reardon, 1994; Moore \& Reardon, 1987). There, however, is a gap in the literature regarding social media use for sport brands, the endorsement effect of Facebook likes, and whether likes influence consumer behavior. Furthermore, industry regulators need marketing research that merges "the expertise of consumer experts into regulatory proceedings" (Preston, 1983, p. 2), ultimately enhancing regulatory decisions. Consumer-based research has been used in a legal or regulatory context in intellectual property studies involving trademark dilution (McKenna, 2012; McKenna, 2009; Morrin \& Jacoby, 2000; Tushnet, 2007). Thus, a basis exists for applying nonlegal theory in an empirical setting to gain a better understanding of legal/regulatory problems.

Any law or regulatory-focused empirical study must use an appropriate theoretical lens. This study relied on McCracken's (1989) Meaning Movement and the Endorsement Process theory, which states that the meanings or attributes of the endorser are transferred to the brand, to test the NAD's decision by examining the effects of Facebook likes as consumer endorsements on the brand image of a sport company and consumer purchase intention. McCracken's model was selected for this study because it has been found to be a valid means for measuring endorsement effect; and the NAD's basis for regulating Coastal Contacts was that the company's like-gating practice was a form of social endorsement. Theoretically, this study 
expands application of McCracken (1989)'s theory to the context of social media; practically, the study also offers regulatory agencies like the NAD and FTC as well as sport marketers insight into the potential effects of like-gating campaigns and assesses whether the volume of Facebook likes for a sport brand influences brand image and consumer purchase intention. A study of this nature, using this specific theory to investigate like-gating, to our knowledge has never been performed. It is our objective to develop research that will open the door for marketers to rely on survey data to better navigate existing regulations. Likewise, survey data can guide regulatory agencies in modifying or drafting new guidelines to protect consumers from misleading marketing campaigns conducted through social media.

This article begins with a discussion of endorsement theory and then the specific variables that contribute to the conceptual model. The article then progresses through an explanation of the description of the methods used and the results obtained. Finally, a discussion is provided along with marketing and regulatory implications for sport marketers.

\section{Theoretical Framework and Hypotheses}

Using Endorsement Theory, this study seeks to determine whether the NAD was correct in its holding that the number of Facebook likes is a form of social endorsement which influences brand image and purchase intention. Previous research reveals that courts often use survey instruments to guide factual determinations. One of the earliest documented uses of empirical data in an adjudication process is a National Labor Relations Board (NLRB) case involving Shopping Kart Food Market, Inc. (Shopping Kart Food Market, Inc., 1977). In formulating its decision, the NLRB contemplated a study by Getman and Goldberg (1976) which examined the effects of "union election campaigns on employee predispositions to vote for particular candidates" (O’Meara, 1981, p. 977). Although NLRB overruled its decision in a later case, the decision emphasizes the ability of agencies to rely on research studies for regulatory decisions. The case also stresses the importance of ensuring that survey instruments used in legal/regulatory determinations are grounded in sound theory that has been subjected to peer review.

In Daubert v. Merrill Dow Pharmaceuticals, Inc. (1993), the Dauberts claimed that their child's birth defects were the result of the mother ingesting drugs made by Merrill Dow Pharmaceuticals. Scientific evidence was introduced to support their claims; however, relying on Federal Rule of Evidence 702 (Testimony by Experts), the Supreme Court ruled that the testimony was inadmissible due to the fact that the research was conducted solely for the purposes of litigation. Moreover, the theories and methods applied by the researchers had not been subjected to peer review or publication (Daubert v. Merrell Dow Pharmaceuticals, Inc., 509 U.S. 579 (1993)). Rule 702 also states that the theories used in expert testimony must be generally accepted by the scientific community ("Federal Rules of Evidence," 2012). Given the importance of establishing compliance with Rule 702, the next section discusses the foundations of Endorsement Theory and consumer behavior research. Endorsement Theory served as the theoretical foundation for this investigation because it provided the most reliable means for testing the existence of endorsement effect; and the NAD's holding was that like-gating, as used in the Coastal Contacts case, was a form of social endorsement. This study sought to 
investigate the merits of that holding based on an empirical examination of the endorsement potential of like-gating.

\section{Endorsement Theory}

An endorser is defined as a source of information that contributes to the acceptability of the content of a message (Batra, Aaker, \& Myers, 1995) or in the context of advertising or marketing, the endorser supports or recommends a product or service to an audience. Utilizing endorsers has been a popular marketing and advertising strategy due to their ability to enhance message recall (Friedman \& Friedman, 1979), to create positive attitudes toward a brand (Kamins, Brand, Hoeke, \& Moe, 1989), and to elicit more positive consumer responses toward purchase intention of the endorsed brand/product (Ohanian, 1991). In addition, Aaker (1996) stated that endorsers are not only an opportune way to influence consumers; they are also a basic and effective component of sport marketing.

Several models have been identified to determine the effectiveness of endorsers used in advertising. The first was Hovland, Janis, and Kelley's Source Credibility Model (1953) that asserted that the effectiveness of an advertisement depended on the recognized trustworthiness and expertise of the endorser. The next model was McGuire's Source Attractiveness Model (1985), in which endorser effectiveness was based on the likeability of the endorser, and physical attractiveness was the source of endorser likeability. The third model was called the Product Match-Up Hypothesis, which required a perceived fit between the brand's characteristics and the endorser's image for an advertisement to be effective (Forkan, 1980; Kamins, 1990).

Although there are numerous studies to support each of these theories regarding endorser effectiveness, DeSarbo and Harshman (1985) found that all three models failed to explain critical factors about endorser effectiveness. For example, Kamen, Azhari, and Kragh (1975) suggested that endorsers are at the heart of advertising process. Endorsers help to prompt past associations with the brand by adopting the meanings conveyed through the advertisements (Kamen et al., 1975); endorsers also function as a place, in which meanings about a brand come together (McCracken, 1989). The previous models only addressed the credibility and attractiveness of the endorser, but did not consider the endorser's function as a medium for the advertisement (McCracken, 1989). To address these limitations, the Meaning Transfer Model was introduced (McCracken, 1989).

McCracken (1989) found that advertising is based on the meanings associated with products, and when an endorser is used, these individuals carry their own symbolic meanings to the endorsement process. McCracken (1989) identified three stages of the Meaning Transfer Model. First, the transfer process is initiated by the advertiser who determines what meanings should be attributed to the product (e.g., type of gender, age, status, or lifestyle). Essentially, the advertiser is selecting the appropriate culture (e.g., objects, persons, and context) for the product. In the second stage, the advertiser chooses an endorser who already embodies those characteristics, as the meanings must exist in the endorser themselves. Although anonymous actors and models possess their own meanings that may be used for endorsements, McCracken (1989) found that utilizing celebrities offers more precision with regard to the configurations of meanings that are available for advertisements. Consumers 
will typically associate the celebrity with the roles they portray, and these meanings will also be tied to the advertising campaign. The advertising campaign, in turn, must then isolate and transfer these meanings to the product (McCracken, 1989), guiding the consumer to recognize the resemblances between the celebrity and the product. This leads to the final stage of the process, in which the consumer actually equates the meanings in the celebrity as also within the product. The consumer then chooses to integrate these meanings into their own self-image, and ultimately purchases and uses the product to usurp it meanings (Agrawal \& Kamakura, 1995; Keller, 1993; McCracken, 1988).

Although the Meaning Transfer Theory specifically relates to celebrity endorsements, it was also an effective framework for this study. Essentially, the meanings attributed to social media endorsements by consumers are transferred to the brand, thus influencing perceptions of the brand. As a result, companies have adopted marketing and advertising campaigns to increase the number of Facebook likes on their branded Facebook pages to enhance perceptions of brand image. These likes are then promoted not only on the Facebook pages themselves but also on the company websites. By highlighting the number of likes, companies display to consumers that they possess a specific number of consumer endorsements (Chubb \& Reed, 2011), and these endorsements are used to imply brand quality as well as preference over competing brands.

\section{The Facebook Like as a Consumer Endorsement}

Friedman and Friedman (1979) identified three types of endorsers that are used in advertising: the celebrity, the expert, and the typical consumer. The celebrity was recognized by the public for his or her achievements that are unrelated to the product endorsed; the expert was an established authority on the product endorsed whose education or training distinguishes him or her from the ordinary person. Lastly, the typical consumer was defined as an average person possessing no particular knowledge of the product endorsed except that obtained through ordinary use of the product (Friedman \& Friedman, 1979). Endorsements by the typical consumer are of interest to this study.

Previous research has found that in advertisements without a celebrity endorser, consumers are more likely to pay closer attention to the actual products and the brands rather than being focused on the celebrity (Mehta, 1994). Furthermore, consumers will generally believe that the typical consumer endorser is more honest and sincere regarding the characteristics of a product, ultimately creating a positive association with the brand (Friedman \& Friedman, 1979), and the "mere fact of being associated with a brand implies an endorsement of it" (Kamen et al., 1975, p. 1). In addition, studies have shown that the top reasons for liking a brand were attributed to being a customer (41\%) and to show support (49\%) (Leggatt, 2013). Therefore, Facebook users who like sport brands could be considered consumer endorsers.

\section{Facebook Likes as Multiple Endorsements}

By identifying a single Facebook like as a consumer endorsement, the question is then raised regarding the effects of multiple Facebook likes on a sport brand. 
In advertising practices, it is common to see more than one athlete promoting a brand. For example, for the 1984 Olympic Games, there were 58 athletes wearing Nike ("Nike, Inc. Company History and Information-Nike Repository," 2012), and in 2007, Rolex had endorsement deals with one polo player, one skier, two race car drivers, three yachtsmen, four equestrians, seven tennis players, and 24 golfers (Binkley, 2007).

Hsu and McDonald (2002) revealed that using multiple celebrities to endorse a product can have two outcomes with respect to the transfer of meaning. First, there can be a transfer of an abundance of meanings to the product, if the endorsers possess a varied set of characteristics. Second, if the endorsers have common characteristics, there can be the transfer of a specific, emphasized meaning to the product. Therefore, if the endorsers' meanings complement each other, then increasing the number of endorsers may also increase the range of the meaning transfer to the brand (Seno \& Lukas, 2007). The study further suggested that "multiple celebrity endorsement advertising may help the advertiser build a sense of consensus, avoid audience boredom and appeal to multiple audiences" (Hsu \& McDonald, 2002, p. 25). Kelley (1973) advocated that consensus will guide the strength of the inference. If the consensus is high, a consumer is more likely to deem an appropriate inference has been formulated. Research also indicated that information from multiple sources will enhance consumer perceptions that the information presented is based on several, impartial perspectives, and is therefore, more persuasive than a single-source message (Harkins \& Petty, 1981; Moore \& Reardon, 1987). Furthermore, if multiple people endorse the product, this will also influence the consumer's belief that others have a common view of the product (Mowen \& Brown, 1981). Consequently, the higher the number of endorsements or Facebook likes, the more consumers will believe the brand will be more credible, which supports the NAD's decision that Facebook likes may be misleading to consumers regarding a company's brand image.

\section{Endorsements and Brand Image}

Keller (1993) defined brand image as a consumer's observations about a brand that are based on the brand associations maintained in the consumer's memory. Brand image is essential because it allows a brand to differentiate itself from its competitors (Dolich, 1969), and it influences consumer buying behavior (Fishbein \& Ajzen, 1975; Kotler, Armstrong, Saunders, \& Wong, 1996). A positive brand image also helps to determine a brand's position, augment the brand's market performance, and build long-term brand equity with consumers (Aaker \& Keller, 1990).

In order for brand image to be effective, consumers must create associations within their memory about a brand (Roy \& Cornwell, 2003). When a consumer has developed positive brand associations, the consumer is able to distinguish the product from competing brands (Faircloth, Capella, \& Alford, 2001), and if a brand is to be successful, value and differentiation are essential in the marketplace (Aaker, 1997). There are three brand association components of brand image: product attributes, benefits, and brand attitudes (Plummer, 2000). Attributes are the descriptive features that encompass a product or service; these may be productrelated (e.g., what is needed to perform the product or service, or nonproduct related, price information or where the product is used; Keller, 1993). Benefits are what 
the consumer believes the product can do for them. Park, Jaworski, and MacInnis (1986) further categorized benefits as functional, experiential, and symbolic. Functional benefits will solve consumption-related problems (Fennell, 1978). For example, a runner who lacks energy during the last stretch of a race may seek an energy drink to assist with endurance. Experimental benefits emphasize what it feels like to use a product, such as feelings of pleasure or cognitive stimulation (Keller, 1993). Symbolic benefits involve nonproduct related consumer needs linked with the consumer's self-concept or social approval, such as wearing a sport's jersey to show identification with a particular team. Dolich (1969) found that the most successful marketing strategies can create psychological values for products or brands by highlighting the similarity between these values and the consumer's self-concept. The last association component of brand image is brand attitude. Brand attitudes are the consumer's complete assessment of the brand (Mitchell \& Olson, 1981), which may also include attributes and benefits of the product or brand (Zeithaml, 1988).

Moreover, these associations can vary in strength, favorability, and uniqueness depending on the marketing campaigns that are connected with a product (Keller, 1993). Strength is determined by both the quality and quantity of the information introduced into the consumer's memory (Keller, 1993). The favorability of the association will depend on whether the consumer believes the product or brand has attributes and benefits that relate to their personal needs (Keller, 1993); while, the uniqueness is based on whether the brand provides the consumer with a strong justification for buying the specific brand as opposed to another (Aaker \& Shansby, 1982). Based on these theoretical and empirical supports, the following hypothesis was developed to examine the NAD's holding that like-gating is a form of social endorsement:

$\mathrm{H}_{1}$ : A high number of Facebook likes will influence brand image more than a low number of Facebook likes.

Given the diverse meanings and associations a consumer may possess toward a brand, how can a brand be successful? Ultimately, "an ideal brand would be a combination of all the customer's preferred product associations" (Aaker \& Shansby, 1982, p. 60), and marketers may want to incorporate numerous aspects of brand image into a marketing campaign. One of the most effective ways of addressing brand image is by utilizing secondary association marketing techniques, such as endorsers. When an advertisement includes an endorser, the consumer's image of the endorser is transferred to the brand (McCracken, 1989), thereby strengthening the association in the consumer's memory and increasing the likelihood of purchase intention. With regards to Facebook, if a consumer associates a high number of Facebook likes with a sound brand image, the result should be an increased likelihood of purchase intention.

\section{Purchase Intention}

Keller (2009) stated the stronger the attitude toward the brand, the more likely a consumer will intend to purchase the product. Wang (2005) determined that positive consumer endorsements, and a higher perceived credibility of those endorsements, were most effective when consumers possessed a prior interest in the endorsed product. When a sport consumer who hasn't previously liked a brand on Facebook 
chooses to visit a brand's Facebook page, this is often based on prior interest in the product. Although prior interest may be the impetus for visiting social networking sites (SNSs), the mere fact that sport consumers are turning to this medium for product or brand information highlights the potential influence that SNSs have on consumer behavior and subsequent purchase intentions. Thus, the following hypothesis was proposed to examine the potential influence of like-gating and whether the NAD should regulate this practice based on its potential to influence consumer behavior:

$\mathrm{H}_{2}$ : A high number of Facebook likes will influence consumer purchase intention more than a low number of Facebook likes.

\section{Methodology}

\section{Brand Selection}

To test the hypotheses, this study examined All Sport, which is a sport beverage similar to Gatorade and Powerade. The brand was chosen due to its low familiarity. Previous studies have indicated that brand familiarity influences a consumer's perception of the brand, which in turn affects the individual's purchase intention for the same brand (Laroche, Kim, \& Zhou, 1996). If a subject is very familiar with a brand, it is likely that prior associations with that brand will be integrated into their decision-making processes when assessing the advertisement and the brand (Lafferty \& Goldsmith, 1999). A pilot test was conducted before actual data collection to select a sport beverage with low familiarity. In this pilot test, participants were told that the questionnaire was designed to assess their knowledge of sport brands. Adapted from Kent and Allen (1994), respondents were asked to determine whether they were familiar or unfamiliar with the brand on a 5-point Likert-type scale ranging from 1 "unfamiliar" to 5 "very familiar." The average familiarity score for All Sport was a 1.76, indicating that the brand was optimal for the study.

\section{Design, Participants, and Procedures}

A $3 \times 2$ mixed design of analysis of covariance (ANCOVA) was conducted in this study. The independent variable was number of Facebook likes (no number of likes, low number of likes, and high number of likes). The dependent variables were brand image and purchase intention. Participants were recruited using undergraduate and graduate courses from sport management programs at two southeastern universities via a message which included an e-mail link to an online Qualtrics survey. A snowball sampling design was used, encouraging respondents to send the message to their network of friends, and so on. In 2011, approximately thirty-one percent of Facebook users were between the ages of 18-24 (Corbett, 2011), indicating that a student sample was appropriate for this study. As a result, a total of 521 responses were collected; one was eliminated for failure to consent.

Once agreeing to participate, respondents were then asked to provide information regarding their gender, age, race, education, annual income, and whether they were a Facebook user. An additional 31 surveys were eliminated based on the lack of Facebook usage and due to missing values or responses, resulting in 490 usable 
surveys. In terms of participants' demographic characteristics, gender was evenly distributed (female $=51.5 \%$ ). Approximately $80 \%$ were aged between 18 and 34 . For the ethnicity, a majority of participants were white. Most participants were undergraduate and graduate students (around 95\%). For participant's Facebook use, over $86 \%$ stated that they visited Facebook at least once a day, indicating the participants in this study were active Facebook users.

Participants were then randomly assigned to one of three groups: control group, experiment high, and experiment low and asked about their cognitive response (i.e., brand image) and behavioral response (i.e., purchase intention) toward All Sport. Participants were asked initial questions regarding brand image and purchase intention. If the participant was in the control group, the survey ended following their responses to the initial questions. If the participant was in one of the treatment groups, he or she received either an image of All Sport's Facebook page with a high number of likes (experiment high) or a low number of likes (experiment low). The average brand on Facebook has approximately 40,000 likes (Nutley, 2012). For the experiment high group, the Facebook page for All Sport had 5.6 million likes, grossly exceeding the national average. This number was selected from the number of likes found on Gatorade's Facebook page. In the pilot test used to select a brand for the study, it was determined that Gatorade was the sport beverage with which participants were most familiar. The experiment low group was shown a Facebook page for All Sport with 4,251 likes, grossly below the national average for brand likes on Facebook. The number for experiment low was selected based on the actual number of likes for All Sport on Facebook. The Facebook pages only included the number of likes and did not include images of those who like the brand or information on friends who like the brand. After viewing an excerpt from All Sport's Facebook page, respondents were presented with questions regarding brand image and purchase intention.

\section{Instruments}

Twenty-four items were drawn from prior endorsement and brand image studies to measure the constructs in this study. Brand familiarity was measured utilizing three items from Kent and Allen (1994) based on a 7-point semantic differential scale with bipolar endpoints. Although the choice of brand (All Sport) was rationalized based on the unfamiliarity of brand (Laroche et al., 1996), we assumed that different levels of familiarity toward the All Sport product may exist within the participants. Therefore, brand familiarity was treated as the covariate in this study. In terms of reliability of the Kent and Allen's (1994) brand familiarity scale, Cronbach's alpha showed .97, indicating an excellent internal consistency. Brand image was measured using seven items adapted from Till and Shimp (1998) and based on a 9-point semantic differential scale with bipolar endpoints. The positive endpoints included: good, high quality, superior, beneficial, favorable, positive, and strongly like. Till and Shimp (1998) reported a coefficient alpha ranging from .93 to .98 for the scale's reliability. In this current study, Cronbach's alpha displayed .96 for the brand image scale, indicating the scale was of great internal consistency. Purchase intention was measured with 1 item from Till and Busler (2000) using a 9-point semantic differential scale with bipolar endpoints "definitely would not" and "definitely would." To assess endorsement effect of Facebook's number of likes, 
after viewing the initial product information on All-Sport, the treatment groups were asked to reevaluate the Facebook images applying the Till and Shimp (1998) and Till and Busler (2000) scales.

\section{Results}

The assumption associated with ANCOVA is the homogeneity of regression slopes, which was tested through scatterplots available in SPSS (Field, 2009). The test indicated that there was no violation of the assumption. Therefore, the main analyses were deemed appropriate. Two separate ANCOVAs were conducted to explore the influence of the number of Facebook likes on a consumer's cognitive and behavioral responses. In this study, brand familiarity was treated as the covariate to partial out any variance to ensure that the results from this experiment were only due to the manipulation (i.e., varying levels of number of Facebook likes). Both ANCOVAs revealed that the covariate was not found to be significant $(p=.76)$.

The first ANCOVA examining the effect of number of Facebook likes on brand image revealed a significant main effect $F(2,473)=62.26, p<.001, \eta_{\mathrm{p}}{ }^{2}=.21$. This result supported hypothesis 1 . As hypothesized, the mean score $(M=6.78)$ for the group exposed to high number of Facebook likes was found to be higher for brand image toward All Sport than those for the low number of Facebook likes group $(M$ =4.46) and control group $(M=3.92)$.

The second ANCOVA investigating the influence of number of Facebook likes on purchase intention revealed a significant main effect $F(2,473)=13.10$, $p$ $<.001, \mathrm{~h}_{\mathrm{p}}{ }^{2}=.04$, supporting hypothesis 2 . As expected, the mean score $(M=5.91)$ for the high number of Facebook likes group was found to be higher for purchase intention toward All Sport than those for the low number of Facebook likes group $(M=5.21)$ and control group $(M=5.01)$. Combined, these results indicated that participants who were exposed to the high number of Facebook likes were more likely to positively perceive the brand image as well as purchase the brand compared with those who saw the low number of Facebook likes. These results were possible after controlling for brand familiarity. These results clearly demonstrated that the number of likes on Facebook could be used as an endorsement opportunity for sport marketers.

\section{Discussion and Implications}

The purpose of the study was to examine the NAD's determination in Coastal Contacts that the number of Facebook likes serves as a social endorsement. The study performed this examination by measuring the effects of Facebook likes as consumer endorsements on the brand image of a sport company and consumer purchase intention. The results revealed that both hypotheses were accepted. The number of Facebook likes a brand has significantly influenced brand image, and a high number of likes indeed influenced brand image more than a low number of likes. Furthermore, the number of Facebook likes a sport brand has significantly influenced consumer purchase intention, and a high number of likes influenced consumer purchase intention more than a low number of likes. These findings were consistent with prior studies that found a positive relationship between brand 
image and a brand's presence on Facebook ("Brands' Facebook Pages Strengthen Customer Perception," 2011). The findings from this study also provided support for application of the Meaning Transfer Theory to Facebook likes as a form of social endorsement. Consumers did, in fact, attribute specific meanings in their minds regarding the number of Facebook likes for the sport brand, and the positive meanings associated with a high number of Facebook likes positively influenced brand image. Similarly, the positive perceptions of the brand positively influenced purchase intention. This finding coincides with existing endorsement theory; brands that use endorsers for marketing campaigns can create positive attitudes toward the brand (Kamins et al., 1989) and increase purchase intention (Ohanian, 1991).

Notably, marketing practitioners have assumed the existence of a positive relationship between a brand's number of Facebook likes and its brand image (Bruhn, Schoenmueller, \& Schäfer, 2012; Felix, 2012), but to our knowledge, this is the first time the relationship had been empirically examined. In addition, the findings from this study supported suggestions from previous studies which found that Facebook likes would increase the likelihood that a consumer would purchase a product (Stephen \& Galak, 2012; "The Facebook Like," 2011). This study expanded on those prior studies by comparing the effects of a low number of Facebook likes with a high number of Facebook likes on purchase intention in the context of a sport product.

The findings from this study produced practical and regulatory implications for sport marketers. From a practical perspective, sport brands should actively engage in like-gating practices to increase the number of likes for their Facebook pages. By increasing the number of Facebook likes, sport brands can improve their image and promote consumer purchase intention for their products. For example, Baylor University developed a social media campaign called the Baylor Rewards Program. Fans of Baylor Athletics who posted pictures, shared videos, or checked in to Baylor sporting events earned points for sharing the content and these points could be used to redeem prizes such as licensed merchandise and tickets to Baylor sporting events. During a specific time period, fans who obtained the most points could qualify for unique fan experiences such as season tickets or lunch with a Baylor coach (Scheiner, 2012). At the beginning of the campaign in November 2011, the Baylor Athletics Facebook page had approximately 18,000 likes; as of January 2012, the page had 26,000 likes (Scheiner, 2012). Another example of effective social media marketing was implemented by the National Hockey League's New Jersey Devils. The team created Mission Control, a social media center run by its fans, which allows fans to share ideas and stories about the NJ Devils (Ortiz, 2011). Known as the Devils Army Generals, 25 fans volunteered up to 12 hours a day on game days to interact with other fans about the team. As a result, the team saw an increase from 100,000 likes to 170,000 likes on its Facebook page (Ortiz, 2011) and through two Facebook ticket promotions, the team grossed over \$17,000 in revenue (Scheiner, 2012).

Conversely, like-gating campaigns can have negative consequences for a sport brand if they are executed poorly. In January 2012, Football Club (FC) Bayern Munich announced to its fans that it would broadcast the name of a new player for the Club on its Facebook page. To view the broadcast, fans had to "like" the team's Facebook page (Murphy, 2012). When the announcement was made, the campaign 
revealed a gimmick that allowed Facebook users to appear as the new Club signing. The FC Bayern Munich Facebook page was inundated with over 5,000 negative comments and these comments forced the Club to respond with an apology to its fans (Murphy, 2012). Undoubtedly, the concept was clever, but the execution did not fare well with fans. Therefore, if sport marketers incorporate like-gating campaigns into their marketing and promotional activities, these campaigns should not involve practices that could be deemed misleading to consumers.

\section{Regulatory Implications}

From a regulatory perspective, the NAD's determination that consumers perceive Facebook likes as a form of social endorsement was confirmed by the findings that the number of likes a sport brand has on Facebook influences both brand image and purchase intention. In addition, the study supported the NAD's notion that consumers who rely on the number of Facebook likes to determine brand quality and/or brand image may be misled by false likes, such as those received from likegating campaigns. Accordingly, the NAD was correct to regulate like-gating, and additional NAD and FTC regulatory measures designed to prevent brands from misleading consumers through like-gating practices are advisable. Furthermore, based on the NAD's focus on like-gating, sport marketers should tread cautiously in executing marketing campaigns with like-gating offers. Although Facebook can foster brand awareness and enhance brand image, consumers must, in fact, get the benefit specified in the like-gating offer, and brands must be "sincere in generating and promoting the number of likes as endorsements (i.e., no falsification of likes and no likes given in exchange for compensation or employment)" (Baker, Brison, \& Byon, 2013, p. 115).

Regulatory agencies such as the NAD are rooted in the concept that there must be truth in advertising. Consumers should have enough information about a brand to make an informed purchase decision, and advertisements or marketing campaigns should not be misleading. Even when creating a campaign to increase the number of likes on a Facebook page, companies who do not consider the regulatory implications of these practices may find themselves under scrutiny by the NAD.

The NAD should also consider further monitoring of like-gating practices, for both sport and nonsport brands, to prevent consumers from being misled by likes that have been generated in exchange for something of value rather than likes generated by actual endorsement of the brand. For example, partnering with the social network sites to eliminate false likes may be advisable. In 2012, Facebook launched an investigation into fake likes and determined that $8.7 \%$ of the active user accounts were fake accounts targeted at misleading consumers (Socialbakers.com, 2013). As a result, the company developed safeguards to block accounts that were used solely for like button clicks; last year the company reported that only $0.4 \%-1.2 \%$ of all active users were abusive accounts that created fake likes" (Edwards, 2014, para. 9). Today, the company continues to focus on maintaining the integrity of its site through its policy regarding like-gating: "A Like that doesn't come from someone truly interested in connecting with a Page benefits no one . . .. When a Page and fan connect on Facebook, we want to ensure that connection involves a real person interested in hearing from a specific Page and engaging with that brand's content" (Gross, 2012, para. 5). 


\section{Limitations and Future Research}

Several limitations have been identified with regards to this study. First, this study was limited in that only one type of product (a lower-tier sport beverage) was examined. In the future, different types of products, including nonsport products, should be analyzed as a moderator to determine whether type of product will influence the strength of the relationship between number of Facebook likes and brand image and number of Facebook likes and purchase intention. Furthermore, this study focused the number of Facebook likes and did not examine the influence of friend likes on consumer perception. Research is needed that examines the endorsement effect of friend likes to determine the influence that friends have on social endorsers via Facebook. Despite the fact that brand familiarity was controlled for in this study, future studies could instead use a fictitious brand to account for a participant's prior association with a brand. The frequency of Facebook use and its influence on brand image and purchase intention may also be worth exploring. This study was also limited in that it included a large number of student participants; thus, different populations should be examined in future studies to test the generalizability of the findings. In addition, this study examined Facebook likes, and future studies should examine other forms of social media used by sport entities to determine how they influence brand image and consumer purchase intention. Lastly, it was found that the effect size for the influence of purchase intention was significantly lower than that of brand image in this study. This may indicate that number of Facebook likes may exert more on consumers' cognitive response (e.g., brand image or belief) than the behavioral response (e.g., purchase intention). These results may be explained by Bagozzi's (1992) appraisal-emotional response-coping framework, where cognitive response stemmed from environmental stimuli (in this case, number of Facebook likes) indirectly leads to behavioral response through emotional response. Further, the findings in the current study support a notion that an intermediating variable (e.g., affective response such as satisfaction) should be considered to better understand the decision making process of Facebook like-gating. In future studies, it would be interesting to examine the sequential relationship among brand image (cognitive response), satisfaction (affective response), and purchase intention (behavioral response) following the appraisal-emotional response-coping framework (Bagozzi, 1992) in the context of Facebook like-gating. These suggested research studies may strengthen validation of the NAD's decision as well as other regulatory decisions related to social media. Likewise, additional studies, similar to this one, should be conducted to guide the NAD in its efforts to protect consumers.

\section{References}

Aaker, D.A. (1996). Measuring brand equity across products and markets. California Management Review, 38(3), 102-120. doi:10.2307/41165845

Aaker, D.A. (1997). Should you take your brand to where the action is? Harvard Business Review, 75(5), 135-142.

Aaker, D.A., \& Keller, K.L. (1990). Consumer evaluations of brand extensions. Journal of Marketing, 54(1), 27-41. doi:10.2307/1252171

Aaker, D.A., \& Shansby, J.G. (1982). Positioning your product. Business Horizons, 25(3), 56. doi:10.1016/0007-6813(82)90130-6 
Agrawal, J., \& Kamakura, W.A. (1995). The economic worth of celebrity endorsers: An event study analysis. Journal of Marketing, 59(3), 56-62. doi:10.2307/1252119

Aronica, J. (October 11, 2011). 5 examples of "like-gating" to generate Facebook fans. Retrieved from http://blog.hubspot.com/blog/tabid/6307/bid/27514/5-Examples-ofLike-Gating-to-Generate-Facebook-Fans.aspx

Bagozzi, R.P. (1992). The self-regulation of attitudes, intentions, and behavior. Social Psychology Quarterly, 55(2), 178-204. doi:10.2307/2786945

Batra, R., Aaker, D.A., \& Myers, J.G. (1995). Creative approaches. In Advertising Management (5th ed.). Englewood Cliffs, NJ: Prentice Hall.

BBB.org. (2014). Case reports search. Advertising Self-Regulation-Council of Better Business Bureaus. Retrieved from http://case-report.bbb.org/search/search. aspx ?doctype $=1 \&$ casetype $=1$

Binkley, C. (January 11, 2007). Celebrity watch: Are you a Brad or a James? Pittsburgh Post-Gazette. Retrieved from http://www.post-gazette.com/stories/sectionfront/life/ celebrity-watch-are-you-a-brad-or-a-james-467170/

Bolotaeva, V., \& Cata, T. (2011). Marketing opportunities with social networks. Journal of International Social Networking and Virtual Communities, 2011, 1-8. doi:10.5171/2011.409860

Brands' Facebook pages strengthen customer perception. (August 29, 2011). MarketingProfs. Retrieved from http://www.marketingprofs.com/charts/2011/5801/brands-facebookpages-strengthen-customer-perception

Brison, N., Baker III, T.A., \& Byon, K.K. (2013). Tweets and crumpets: Examining U.K. and U.S. regulation of athlete endorsements and social media marketing. Journal of Legal Aspects of Sport, 23, 55-71.

Bruhn, M., Schoenmueller, V., \& Schäfer, D.B. (2012). Are social media replacing traditional media in terms of brand equity creation? Management Research Review, 35(9), 770-790. doi:10.1108/01409171211255948

Chubb, S.S., \& Reed, M.H. (2011, November 22). NAD reviews "like-gated" Facebook promotional deal, determines "likes" convey "social endorsement." Retrieved from http:// www.lexology.com/library/detail.aspx?g=3afecaed-6c4b-4191-8e4a-0b67d84e5029

Coastal Contacts, Inc., NAD Case \#5387. (October 25, 2011).

Cohen, H. (2012). What's the value of a like? Retrieved February 27, 2012, from http:// www.heidicohen.com/whats-the-value-of-a-like/

Corbett, P. (2011, January 3). 2011 Facebook demographics and statistics-including federal employees and gays in the military. iStrategyLabs. Retrieved from http://istrategylabs. com/2011/01/2011-facebook-demographics-and-statistics-including-federal-employees-and-gays-in-the-military/

Daubert v. Merrell Dow Pharmaceuticals, Inc., 509 U.S. 579 (1993).

DeSarbo, W.S., \& Harshman, R.A. (1985). Celebrity and brand congruence analysis. In J.H. Leigh \& C.R. Martin (Eds.), Current Issues and Research in Advertising (Vol. 4, pp. 17-52). MI: University of Michigan.

Dolich, I.J. (1969). Congruence relationships between self images and product brands. JMR, Journal of Marketing Research, 6(1), 80-84. doi:10.2307/3150001

$\mathrm{Du}$, S., Bhattacharya, C.b., \& Sen, S. (2010). Maximizing business returns to corporate social responsibility (CSR): The role of CSR communication. International Journal of Management Reviews, 12(1), 8-19. doi:10.1111/j.1468-2370.2009.00276.x

Edwards, J. (2014, February 11). Facebook advertisers complain of a wave of fake likes rendering their pages useless. Business Insider. Retrieved from http://www.businessinsider.com/facebook-advertising-fake-likes-2014-2

Facebook newsroom. (2014). Retrieved from http://newsroom.fb.com/company-info/

Faircloth, J.B., Capella, L.M., \& Alford, B.L. (2001). The effect of brand attitude and brand image on brand equity. Journal of Marketing Theory and Practice, 9(3), 61. 
Federal Rules of Evidence. (2010, December 1). U.S. Government Printing Office. Retrieved from http://www.uscourts.gov/uscourts/rulesandpolicies/rules/2010\%20rules/evidence. pdf

Federal Rules of Evidence. (2012, January 3). U.S. Government Printing Office. Retrieved from http://www.gpo.gov/fdsys/pkg/USCODE-2011-title28/pdf/USCODE-2011-title28-app-federalru-dup2.pdf

Felix, S. (2012, August 17). The 20 most-liked Facebook companies ever. Business Insider. Retrieved from http://www.businessinsider.com/the-20-most-liked-companies-onfacebook-2012-8

Fennell, G. (1978). Consumers' perceptions of the product-use situation. Journal of Marketing, 42(2), 38-47. doi:10.2307/1249884

Field, A. (2009). Discovering Statistics Using SPSS (3rd ed.). London, UK: Sage Publications.

Fishbein, M., \& Ajzen, I. (1975). Belief, Attitude, Intention, and Behavior: An Introduction to Theory and Research. Reading, MA: Addison-Wesley.

Forkan, J. (1980). Product match-up key to effective star presentations. Advertising Age, $51(6), 42$.

Friedman, H.H., \& Friedman, L. (1979). Endorser effectiveness by product type. Journal of Advertising Research, 19(5), 63-71.

Gross, D. (September 27, 2012). Facebook cracking down on fake "likes." CNN. Retrieved from http://www.cnn.com/2012/09/27/tech/social-media/facebook-fake-likes/index. html

Harkins, S.G., \& Petty, R.E. (1981). Effects of source magnification of cognitive effort on attitudes: An information-processing view. Journal of Personality and Social Psychology, 40(3), 401-413. doi:10.1037/0022-3514.40.3.401

Hovland, C., Janis, I., \& Kelly, H. (1953). Persuasion and communication. New Haven: Yale University Press.

How social media impacts brand marketing. (October 14, 2011). Nielsen Wire. Retrieved from http://blog.nielsen.com/nielsenwire/consumer/how-social-media-impacts-brandmarketing/

Hsu, C., \& McDonald, D. (2002). An examination on multiple celebrity endorsers in advertising. Journal of Product and Brand Management, 11(1), 19-29. doi:10.1108/10610420210419522

Johnson, C. (February 11, 2009). Cutting through advertising clutter. CBS News. Retrieved from http://www.cbsnews.com/8301-3445_162-2015684.html

Kamen, J.M., Azhari, A.C., \& Kragh, J.R. (1975). What a spokesman does for a sponsor. Journal of Advertising Research, 15(2), 17-24.

Kamins, M.A. (1990). An Investigation into the "match-up" hypothesis in celebrity advertising: When beauty may be only skin deep. Journal of Advertising, 19(1), 4-13. doi:10 $.1080 / 00913367.1990 .10673175$

Kamins, M.A., Brand, M.J., Hoeke, S.A., \& Moe, J.C. (1989). Two-sided versus one-sided celebrity endorsements: The impact on advertising effectiveness and credibility. Journal of Advertising, 18(2), 4-10. doi:10.1080/00913367.1989.10673146

Keller, K.L. (1993). Conceptualizing, measuring, and managing customer-based brand equity. Journal of Marketing, 57(1), 1-22. doi:10.2307/1252054

Keller, K.L. (2009). Building strong brands in a modern marketing communications environment. Journal of Marketing Communications, 15(2/3), 139-155. doi:10.1080/13527260902757530

Kelley, H. (1973). The processes of causal attribution. American Psychologist, 28, 107-128.

Kent, R., \& Allen, C. (1994). Competitive interference effects in consumer memory for advertising: The role of brand familiarity. Journal of Marketing, 58(3), 97-105.

Kotler, P., Armstrong, G., Saunders, J.A., \& Wong, V. (1996). Principles of Marketing (European Edition). Hemel Hempstead: Prentice-Hall. 
Lafferty, B.A., \& Goldsmith, R.E. (1999). Corporate credibility's role in consumers' attitudes and purchase intentions when a high versus a low credibility endorser is used in the ad. Journal of Business Research, 44(2), 109-116. doi:10.1016/S0148-2963(98)00002-2

Laroche, M., Kim, C., \& Zhou, L. (1996). Brand familiarity and confidence as determinants of purchase intention: An empirical test in a multiple brand context. Journal of Business Research, 37(2), 115-120. doi:10.1016/0148-2963(96)00056-2

Leggatt, H. (July 2, 2013). Multiple reasons for liking a brand on Facebook. Retrieved from http://www.bizreport.com/2013/07/multiple-reasons-for-liking-a-brand-on-facebook. html

Mahan, J. E. (2011). Examining the predictors of consumer response to sport marketing via digital social media. International Journal of Sport Management and Marketing, 9, 254-267.

Mangold, W. G., \& Faulds, D. J. (2009). Social media: The new hybrid element of the promotion mix. Business Horizons, 52, 357-365.

Manjoo, F. (2011, July/August). (Like) + (Retweet) = \$\$. Fast Company, 157, 86-117.

McBurney, R. (January 26, 2012). What's the worth of a consumer "liking" your brand on Facebook? FaceTime Strategy. Retrieved from http://www.facetimestrategy.com/ whats-the-worth-of-a-consumer-liking-your-brand-on-facebook/

McCracken, G. (1988). Culture and Consumption: New Approaches to the Symbolic Character of Consumer Goods and Activities. Bloomington, IN: Indiana University Press.

McCracken, G. (1989). Who is the celebrity endorser? Cultural foundations of the endorsement process. The Journal of Consumer Research, 16(3), 310-321. doi:10.1086/ 209217

McGuire, W. (1985). Attitudes and attitude change. In G. Lindzey \& E. Aronson (Eds.), Handbook of Social Psychology (3rd ed, pp. 233-346). New York, NY: Taylor \& Francis.

McKenna, M.P. (2009). Testing modern trademark law's theory of harm. Iowa Law Review, 95, 63-117. 9

McKenna, M.P. (2012). A consumer decision-making theory of trademark law. Virginia Law Review, 98, 67-141.

Mehta, A. (1994). How advertising response modeling (ARM) can increase ad effectiveness. Journal of Advertising Research, 34, 62-62.

Mitchell, A.A., \& Olson, J.C. (1981). Are product attribute beliefs the only mediator of advertising effects on brand attitude? JMR, Journal of Marketing Research, 18(3), 318-332. doi: $10.2307 / 3150973$

Moore, D.J., Mowen, J.C., \& Reardon, R. (1994). Multiple sources in advertising appeals: When product endorsers are paid by the advertising sponsor. Journal of the Academy of Marketing Science, 22(3), 234-243. doi:10.1177/0092070394223004

Moore, D.J., \& Reardon, R. (1987). Source magnification: The role of multiple sources in the processing of advertising appeals. JMR, Journal of Marketing Research, 24(4), 412-417. doi:10.2307/3151389

Morrin, M., \& Jacoby, J. (2000). Trademark dilution: Empirical measures for an elusive concept. Journal of Public Policy \& Marketing, 19(2), 265-276. doi:10.1509/ jppm.19.2.265.17137

Mowen, J., \& Brown, S. (1981). On explaining and predicting the effectiveness of celebrity endorsers. Advances in Consumer Research. Association for Consumer Research ( $U$. S.), 8(1), 437-441.

Murphy, C. (2012, January 27). Snatching defeat from the jaws of victory: Bayern's PR own goal. CNN. Retrieved from http://edition.cnn.com/2012/01/26/sport/football/footballbayern-signing-facebook/index.html

New Balance. (2014). Facebook. Retrieved from http://www.facebook.com/Newbalance

Nike, Inc. company history and information-Nike repository. (2012). Retrieved from http:// www.nikerepository.com/nike-company-history 
Nutley, M. (June 25, 2012). How the average brand behaves in social media. CMO. Retrieved from http://www.cmo.com/content/cmo-com/home/articles/2012/6/25/how-theaverage-brand-behaves-in-social-media.html

O'Meara, V.A. (1981). FTC deceptive advertising regulation: A proposal for the use of consumer behavior research. Northwestern University Law Review, 76, 946.

O’Reilly, N., Berger, I., Hernandez, T., Parent, M., \& Seguin, B. (2012). Understanding adolescent sport participation through online social media. Sport, Business and Management: An International Journal, 2, 69-81.

Ohanian, R. (1991). The impact of celebrity spokespersons' perceived image on consumers' intention to purchase. Journal of Advertising Research, 31(1), 46-54.

Ortiz, M.B. (2011, May 2). Devils fans power "Mission Control." ESPN. Retrieved from http://sports. espn.go.com/espn/page2/story?page=burnsortiz/110502_nhl_social_media\&sportCat=nhl

Park, C.W., Jaworski, B.J., \& MacInnis, D.J. (1986). Strategic brand concept-image management. Journal of Marketing, 50(4), 135-145. doi:10.2307/1251291

Petty, R.E., Cacioppo, J.T., \& Schumann, D. (1983). Central and peripheral routes to advertising effectiveness: The moderating role of involvement. The Journal of Consumer Research, 10(2), 135-146. doi:10.1086/208954

Pew Research Center. (2014). Social networking fact sheet. Retrieved from http://www. pewinternet.org/fact-sheets/social-networking-fact-sheet/

Plummer, J.T. (2000). How personality makes a difference. Journal of Advertising Research, 40(6), 79-83.

Preston, I.L. (1983). A review of the literature on advertising regulation. Current Issues \& Research in Advertising, 6(2), 1.

Reebok. (2014). Facebook. Retrieved from http://www.facebook.com/Reebok

Romanik, L. (2011, June 15). Is your marketing strategy using this powerful principle? Entrepreneurs-Journey.com. Retrieved from http://www.entrepreneurs-journey. com/6803/is-your-marketing-strategy-using-this-powerful-principle/

Roy, D.P., \& Cornwell, T.B. (2003). Brand equity's influence on responses to event sponsorships. Journal of Product and Brand Management, 12(6), 377-393. doi:10.1108/10610420310498803

Scheiner, T. (2012, February 15). Four winning sports social media marketing campaigns you can learn from. Brafton. Retrieved from http://www.brafton.com/blog/four-winningsports-social-media-marketing-campaigns-you-can-learn-from

Seno, D., \& Lukas, B.A. (2007). The equity effect of product endorsement by celebrities: A conceptual framework from a co-branding perspective. European Journal of Marketing, 41(1/2), 121-134. doi:10.1108/03090560710718148

Shopping Kart Food Market, Inc., 228 N.L.R.B. 1311 (1977).

Stephen, A.T., \& Galak, J. (2012). The effects of traditional and social earned media on sales: a study of a microlending marketplace. JMR, Journal of Marketing Research, 49(5), 624-639 (JMR). doi:10.1509/jmr.09.0401

The Facebook Like. (2011, November 10). Razorfish Search. Retrieved from http://razorfishsearch.com/2011/11/10/the-facebook-like/

Till, B.D., \& Busler, M. (2000). The match-up hypothesis: Physical attractiveness, expertise, and the role of fit on brand attitude, purchase intent and brand beliefs. Journal of Advertising, 29(3), 1-13. doi:10.1080/00913367.2000.10673613

Till, B.D., \& Shimp, T.A. (1998). Endorsers in advertising: The case of negative celebrity information. Journal of Advertising, 27, 67-82.

Tripp, C., Jensen, T.D., \& Carlson, L. (1994). The effects of multiple product endorsements by celebrities on consumers' attitudes and intentions. The Journal of Consumer Research, 20, 535-547. doi:10.1086/209368

Tushnet, R. (2007). Gone in sixty milliseconds: Trademark law and cognitive science. Texas Law Review, 86, 507. 
Wallace, L., Wilson, J., \& Miloch, K. (2011). Sporting Facebook: A content analysis of NCAA organizational sport pages and Big 12 conference athletic department pages. International Journal of Sport Communication, 4, 422-444.

Wang, A. (2005). The effects of expert and consumer endorsements on audience response. Journal of Advertising Research, 45, 402-412.

Zeithaml, V.A. (1988). Consumer perceptions of price, quality, and value: A means-end model and synthesis of evidence. Journal of Marketing, 52(3), 2-22. doi:10.2307/1251446 